\title{
Towards a Knowledge Sharing Model for Small Businesses
}

\author{
Jun $\mathrm{Xu}^{1}$, Mohammed Quaddus ${ }^{2}$ and Xiangzhu Gao ${ }^{3}$ \\ Southern Cross Business School, Southern Cross University ${ }^{1,3}$ \\ Lismore, NSW 2480, Australia ${ }^{1,3}$ \\ Graduate School of Business, Curtin University ${ }^{2}$ \\ E-mail: jun.xu@scu.edu.au'; quaddusm@gsb.curtin.edu.au²; xiangzhu.gao@scu.edu.au ${ }^{3}$
}

\begin{abstract}
Small businesses contribute significantly in economy. However, a significant number of small businesses fail in five to ten years. Can knowledge sharing in these businesses make a difference? Research has found that knowledge sharing enhances organisational competitiveness and growth in medium and large enterprises. However, there is a lack of empirical studies on knowledge sharing in the domain of small businesses. This research aims to close the gap by developing a model for understanding knowledge sharing in small businesses. The model will be primarily built on Lipshitz et al.'s naturalistic decision modelling approach, Rogers' innovation diffusion theory, and Ajzen \& Fishbein's theory of reasoned action. The model presents various factors and variables affecting knowledge sharing in small businesses in detail, and thus has both theoretical and practical implications. For the model, hypotheses are proposed, which will be tested in future empirical studies.
\end{abstract}

Keywords: Knowledge Management, Knowledge Sharing, Small Businesses, Naturalistic Decision Modelling, Innovation Diffusion Theory, Theory of Reasoned Action, Knowledge Sharing Model

\section{Introduction}

Small business is classified by various quantitative measures, including number of employees, sale revenues, total assets and net assets ${ }^{1}$. According to the Australian Bureau of Statistics ${ }^{2}$ (ABS), a small business is defined as an organisation with fewer than 20 employees in this research. According to the latest report from $\mathrm{ABS}^{3}$, there were 1,961,337 small businesses in Australia by the end of June 2009. Small businesses represented $96 \%$ of all private sector businesses and employed around 4.8 million people, or over $48 \%$ of the private sector workforce. Small businesses are economic drivers of most nations all over the world ${ }^{4}$ and a large amount of economic activities are conducted by these businesses. How they manage knowledge is viewed as a key factor of their success ${ }^{5}$.

Knowledge management has risen from practitioner and consultancy knowledge since the start of the twenty-first century ${ }^{6}$. The ability to manage knowledge is crucial in today's knowledge economy ${ }^{7}$, and can attain and maintain sustainable competitive advantage and superior economic performance ${ }^{8}$. Over the years, there is an abundance of research describing how large companies are successfully practising knowledge management, but there is little contribution on the critical success factors for knowledge management adoption in small businesses ${ }^{4,5,9,10}$. There is a general consensus that the benefits of knowledge management have not been fully exploited by small businesses ${ }^{10}$.

Some small businesses may still not realise that knowledge is an important value driver ${ }^{11}$. Founders or managers of small businesses are occupied by day-today business operations ${ }^{12}$, which may prevent them from identifying and recognising the benefits of knowledge management. However, literature indicates that there is no relationship between organisational size and the need for knowledge, and there is no significant relationship between the size and innovation ${ }^{13}$. Knowledge management is not less significant to the success of small businesses than that of large businesses. Instead, a suitable handling of knowledge is an especially important factor as to whether a business, large or small, survives. In a knowledge-driven 
economy, managing knowledge is a challenge faced by small businesses ${ }^{4}$. The field of knowledge management in small businesses is highly important ${ }^{13}$.

Prior research in knowledge management has tended to emphasise large businesses. Many researchers compare knowledge management activities in large businesses with those in smaller businesses, assuming that these businesses are comparable ${ }^{13}$. However, small businesses operate differently than large enterprises in some ways", and small businesses are not "merely a scaled-down version of a large business",14 or "little big firms" . The difference exists in the practices around a wide range of management activities ${ }^{5}$. Scholars have been advised to discuss knowledge management with a stronger contextualisation to the specific needs of small businesses rather than from a prescriptive point of view $^{13}$. Dalkir ${ }^{7}$ indicated that organisations can generate value by sharing knowledge. Hutchison and Quintas ${ }^{15}$ showed that knowledge-sharing activities are less likely to be found in small businesses, while sharing knowledge among employees makes small businesses less susceptible to the loss of their knowledge ${ }^{4}$. Therefore there is a need to understand the determinants for knowledge sharing in small businesses in order to improve their competitiveness ${ }^{9}$.

This research is aimed to understand knowledge sharing in small businesses. The objectives of this paper are:

- $\quad$ examining features of small businesses in terms of knowledge sharing,

- investigating the determinants for knowledge sharing in small businesses, and

- proposing a knowledge sharing model for small businesses.

In Section 2, theories about knowledge sharing in small business are presented as a background to the study. In Section 3, characteristics of small businesses are examined, determinants for knowledge sharing are identified, and a knowledge sharing model for small businesses is proposed. Finally, in Section 4, conclusions and future research directions are discussed.

\section{Background}

A lot of research has been done on the knowledge management in large organisations. However the literature on the knowledge management in small businesses is very limited and only provides fragmented insights $^{13}$. This section reviews the theories for understanding determinants for sharing knowledge in small businesses.

\subsection{Knowledge Management and Knowledge Sharing}

Knowledge management is "an approach to adding or creating value by more actively leveraging the knowhow, experience, and judgment [that] reside within and, in many cases, outside of an organization"16. Although not identifying knowledge management activities, this definition highlights knowledge elements, which are normally classified as explicit knowledge, which can be easily captured and codified; and tacit or implicit knowledge, which is difficult to capture and formalise ${ }^{17,18}$. Dalkir ${ }^{7}$ defined knowledge management in the perspectives of organisations and activities: knowledge management is the deliberate and systematic coordination of an organisation's people, technology, processes and organisational structure in order to add value through the promotion of creating, sharing and applying knowledge. Both definitions indicate that successful knowledge management adds value to organisations. However, approaches to knowledge management can be different depending on the organisational context and the knowledge categories.

According to Nonaka \& Takeuchi $^{19}$, tacit knowledge consists of two dimensions: cognitive dimension, which refers to 'mental models' that assist human beings in interpreting and understanding the world around them; and technical dimension, which refers to operational expertise that assists human beings in undertaking tasks. Examples of cognitive knowledge include individuals' perspectives, beliefs and opinions; and examples of technical knowledge include crafts and skills. Tacit knowledge is personal and subjective; therefore it is difficult to formalise and communicate. In contrast with tacit knowledge's subjective nature, explicit knowledge is more objective and generally can be codified or documented in a formal or systematic format. Information from databases or libraries, and the Web is some examples of explicit knowledge.

Nonaka and Takeuchi $^{19}$ modelled knowledge creation, sharing and utilisation processes by four modes of Socialisation, Externalisation, Combination and Internalisation (SECI):

- Socialisation refers to the transmission of tacit knowledge to tacit knowledge, sharing knowledge among individuals through face-to-face contact 
such as interviews, focus groups, conversations at lunchtime and coffee/tea breaks, on-the-job training, master-fellow-relationships, and brainstorming.

- Externalisation refers to the conversion of tacit knowledge to explicit knowledge in the form of metaphors, analogies, hypotheses and models, articulating tacit knowledge obtained through observation, imitation, and practice into a format that can be easily used in the future.

- Combination is the creation of new explicit knowledge based on existing pieces of explicit knowledge by sharing, combining, organising and processing these discrete bodies of knowledge.

- Internalisation refers to the conversion of explicit knowledge to part of tacit knowledge. This mode regards the activities of applying knowledge in practice and reflects the concept of learning by doing. For example, students understand the explicit knowledge (e.g. concept, theories or guidelines) from books and classroom to acquire their own tacit knowledge (e.g. skills or ability) to solve problems in reality.

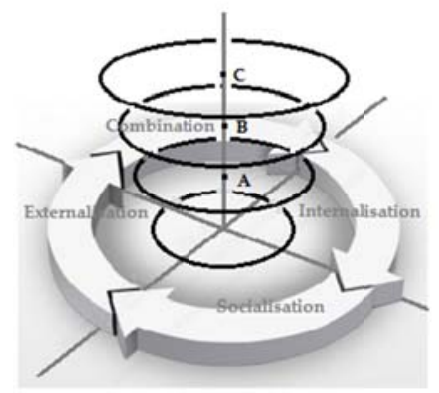

Fig. 1. SECI Model

Fig. 1 demonstrates the SECI model by presenting a spiral, where there is a dynamic intertwining of tacit and explicit knowledge in each of the four modes. The spiral becomes larger in scale time and again. This is a neverending process that upgrades itself, instead of repeating itself $^{20}$. The A, B or C indicates a level of maturity of knowledge management in an organisation, where $\mathrm{B}$ is more mature than $\mathrm{A}$, and $\mathrm{C}$ is more mature than $\mathrm{B}$. Each organisation follows its own dynamic spiral, which is determined by the enablers or the context in which knowledge is managed.

Knowledge sharing activities could happen in all the four modes and there are four enablers for knowledge sharing. Small businesses are often different than large businesses in terms of technology that supports knowledge sharing, culture that influences the attitude towards knowledge sharing, organisational structure that affects knowledge sharing style, and motivation that determines knowledge sharing strategy.

Technology - Knowledge management tools support knowledge sharing in each of the modes of the SECI model. For example, teleconferencing technologies can be used in Socialisation to connect people, and create and sustain knowledge communities where tacit knowledge is shared. When tacit knowledge is made explicit in Externalisation, it can be shared by other employees via groupware tools, electronic mail and databases. In Combination, new explicit knowledge can be disseminated among employees on intranets. In Internalisation, explicit knowledge is shared throughout an organisation on discussion board for individuals to learn by doing.

Culture - Establishing a sharing culture is important for successful knowledge sharing. Individuals tend to share knowledge if it is in their economic or evolutionary self-interest to do $\mathrm{so}^{21}$. Changing the existing culture and people's work habits are the main hurdles for most knowledge management programs ${ }^{22}$. Studies such as Chase ${ }^{23}$, The Conference Board ${ }^{24}$, The Delphi Group $^{25}$ and Zyngier $^{26}$ indicate that lacking a knowledge sharing culture is the biggest obstacle to knowledge management.

Organisational structure - Knowledge sharing is about breaking down barriers within an organisation. An organisational structure facilitating knowledge sharing should also be in place, especially while organisations are working on cross-functional and/or enterprise-wide knowledge sharing ${ }^{27,28}$. A knowledge sharing structure encourages the development of 'communities of practices' and discourages the traditional silo structure in order to gain the maximised benefits from knowledge ${ }^{29}$.

Motivation - Previous research has indicated that knowledge sharing has positive impact on business growth and performance. Hendricks ${ }^{8}$ pointed out that knowledge sharing provides a direct link with organisation's economic and competitive value. Specially, knowledge sharing within a supply chain has become a common practice because it promises to enhance competitive advantage ${ }^{30}$. 


\subsection{Naturalistic Decision Modelling Approach}

Naturalistic Decision Modelling (NDM) has been applied in many complex environments ranging from Navy $^{31}$, nursing ${ }^{32}$ to physicians ${ }^{33}$. However, this research will use the concept of NDM for the first time in knowledge sharing domain. NDM primarily deals with five factors which depart significantly from rational and formal decision making modelling. The key points of NDM approach is its reliance on a single (or at most two) decision option and its emphasis on implementation.

NDM emphasises the real-world decision making situations. The most common NDM factors are:

- individuals who are involved in the decision making process and their expertise of the situation (proficient decision makers);

- situation-action matching decision rule that a decision is taken by matching with the real situation rather than choice, which quickly discards many options and deals with one or at most two options;

- context-bound informal modelling, which identifies issues typical to the specific context of the decision situation and uses them in an informal way to arrive at a decision, rather than casting them into some sort of formal modelling;

- process orientation, which deals with cognitive processes of the decision makers rather than inputoutput orientation of rational and formal decision process; and

- empirical based prescription, which means that prescriptions that cannot be implemented are worthless, even if they are optimal in some formal sense.

\subsection{Theory of Diffusion of Innovations}

Performance improvement is one of the motivation factors for sharing knowledge. Wang \& Chang $^{34}$ suggested that there should be a direct relationship between innovation and performance of small businesses, and knowledge is considered as the raw material of innovation ${ }^{35}$. Regarding the factors that affect the adoption of an innovation, in his theory of diffusion of innovations, Rogers ${ }^{36}$ suggested five perceived attributes of an innovation:

- relative advantage - "the degree to which an innovation is perceived as better", which measures both explicit and implicit advantages;

- compatibility - "the degree to which an innovation is perceived as being consistent with the existing values, past experiences, and needs of potential adopters", which measures how compatible an innovation is with the existing culture, structure, infrastructure, and previously adopted ideas;

- complexity - "the degree to which an innovation is perceived as difficult", which measures how difficult an innovation is to understand, learn and use;

- trialability - "the degree to which an innovation may be experimented with on a limited basis", which describes how easy an innovation is to try out or test; and

- observability - "the degree to which the results of an innovation are visible to others", which reflects how explicit are the results and outcomes of an innovation.

These attributes will be considered for the determinants to share knowledge for innovations in small business.

According Rogers ${ }^{36}$, other variables also affect the adoption of an innovation, such as the type of innovation-decision, the nature of communication channels diffusing the innovation at various stages in the innovation-decision process, the nature of the social system, and the extent of change agents' effort in diffusing the innovation.

\subsection{The Theory of Reasoned Action}

Small businesses need a culture that facilitates knowledge sharing by human communication and interaction $^{37}$. "Designed to explain virtually any human behaviour", the theory of reasoned action (TRA) predicts and explains human behaviour across a wide variety of domains ${ }^{38}$. The TRA has broad applicability in diverse disciplines and has gone through rigorous testing, which has proved its robustness in predicting intentions and behaviour ${ }^{39,40,41}$.

TRA views a person's intention to perform (or not to perform) a behaviour (e.g. sharing knowledge) as the immediate determinant of the actual action. A person's beliefs or perceptions about the characteristics of the target system (e.g. knowledge sharing system) are antecedent to behaviour intent to adopt and use the system $^{42}$. Even though it is possible that intention can change with the passage of time, previous research has shown that they are good predictors of actual future use $^{40}$.

Based on TRA, a person's intention is a function of two basic determinants, one being "personal" in nature and the other one reflecting "social influence". The 
personal factor is the individual's positive or negative evaluation of performing the behaviour, which is called "attitude toward the behaviour", and refers to attitudinal factors. The second determinant of intention is the person's perception of the social pressure put on him/her to perform or not to perform the behaviour in question. This factor is termed "subject norm", which deals with perceived prescriptions and relates to the normative considerations $^{38}$.

Many previous studies have documented the roles of various external variables on system usage behaviour, including individual factors, management factors, organisational factors and system features, among many others. However, TRA considers that external variables such as the system characteristics, task characteristics, user characteristics, political influences, organisational factors and the development or implementation process only have indirect influence on behaviour by affecting beliefs, attitudes and intentions ${ }^{38}$.

\section{Modeling Knowledge Sharing in Small Businesses}

\subsection{Characteristics of Small Businesses}

Many scholars argued that small businesses do not manage knowledge the way large organisations do ${ }^{13,43}$. Literature has discussed peculiarities that differentiate knowledge management practices in small businesses and larger businesses. Small businesses may be differentiated from larger companies by a number of key characteristics, which affect knowledge management practices.

Tacit knowledge in nature - There is a lack of explicit knowledge repositories ${ }^{44}$, and knowledge generated in small businesses tends to be tacit in nature ${ }^{45}$. Most knowledge is usually kept in the minds of the owner and some key employees rather than physically stored or shared through substitution arrangements ${ }^{46}$.

Resource scarcity for operation - Small businesses commonly face resource limitations ${ }^{13,47,48,49}$. They have to take their resource constraints into consideration for knowledge management. They may not have much money to spend on knowledge management initiatives ${ }^{37}$, and are rarely supported by purposely designed systems of information and communication technology ${ }^{50}$.

Proximity in workplace - Employees are likely to have direct contact to each other ${ }^{51}$. Given this proximity the employees are more familiar with each other compared to large organisations. Familiarity and mutual understanding among the employees bred trust and thus promote knowledge sharing ${ }^{43}$. Also there is less competition among the employees compared to their counterparts in larger businesses, and thus they tend to be more willing to share knowledge ${ }^{52}$.

Appreciation of relational capital - Small businesses value human and relational capital $^{53}$, and manage knowledge in a humanistic way ${ }^{44}$. Many of them feel that their development is due to the quality of their employees and the relationships with customers ${ }^{53}$. Knowledge is often created, shared and transferred through members of the businesses. Small businesses use the relational capital and knowledge stemming from their partnerships and collaborative work to increase their performance ${ }^{44,46}$.

Informal organisational structure - Small businesses are generally less bureaucratic in decision-making and have an informal organisational structure ${ }^{43,48}$. The owner-manager of an organisation tends to take on a central position ${ }^{54}$, and therefore decision-making is limited to only one person ${ }^{55}$. This limitation signifies that the owner-manager is responsible for recognising the benefits of knowledge management, and control tends to be based on the owner's personal supervision ${ }^{56}$. They are often introverted, burdened by old traditions, inflexible and resistant to change ${ }^{49,57}$.

Cross functionality of staff - Small businesses often compensate for their smaller size by managing more strategically their human resources ${ }^{58}$. The success of small businesses is influenced by the knowledge, experience and skills of the owners and its employees ${ }^{59}$. They are more likely to be skilled at avoiding pitfalls of knowledge loss ${ }^{44}$. Employees are usually required to undertake more than one functional responsibility, resulting in overlapping roles with other colleagues. Cross functionality and overlapping roles generally lead to more knowledge sharing ${ }^{43}$. The close social ties between employees often act as deterrence against them leaving the business ${ }^{13}$. In cases where employees do leave the business, their responsibilities could be easily undertaken by other staff or the owner, who may have a deeper knowledge and would in turn guide the next junior employee ${ }^{43}$.

Ad hoc fashion of management - The performance of small businesses is far from one-dimensional and greatly depends on the environmental context in which 
the company evolves, or the competitive advantage on which it depends to break away from its competitors $^{34,60,61}$. Some activities of knowledge management are often practiced but in an 'ad hoc' fashion. The activities must be adapted to the business' needs but not the other way round ${ }^{10}$. Knowledge must be managed dynamically so that business goals can be achieved in an effective and efficient manner ${ }^{62}$. Knowledge management needs to be reactive to the environment and fire-fighting to meet dynamic challenges $^{48}$.

Informal control on knowledge - Small businesses often do not see knowledge management as a crucial function for their success ${ }^{50}$, although concepts and vocabulary of knowledge management are increasingly acknowledged and applied in small businesses ${ }^{15}$. Tools are often not considered as instruments for knowledge management. They have the tendency to put knowledge generated immediately into practice instead of storing it $^{4,44}$. Large businesses generally rely on systematic mechanisms to manage knowledge ${ }^{9}$. But a systematic approach to knowledge management in smaller businesses is missing, and small businesses have adopted informal controls on knowledge ${ }^{5}$. There is an absence of systematic knowledge management in many small businesses ${ }^{63}$.

\subsection{Determinants for Knowledge Sharing in Small Businesses}

Previous sections introduced the NDM, which describes how people make decisions in the complex real world; the Theory of Diffusion of Innovations, which identifies the attributes of innovation; and TRA, which establishes direct relationship between intention and behaviour; and also examines the nine characteristics of small businesses in terms of knowledge sharing. Based on the introduction and examination, eight determinants for knowledge sharing in small businesses are investigated by identifying and explaining the variables of each determinant in this section. A model for knowledge sharing in small businesses is proposed in Section 3.3.

Variables of the External Push are identified and explained in Table 1.

Organisations exist within an "open” environment, where external fluctuation such as changes in the marketplace influences internal operation ${ }^{64,65}$. Small businesses have to adopt ad hoc fashion of management to meet the dynamic changes in environmental context, including competitors and market. Logically, small businesses' knowledge management initiatives have been ignited by the tough competition and intensive competitive pressure in the market place and challenges from customers, who are demanding more value-formoney and expecting better services. Also it is not surprised that small businesses would have the need to share knowledge with its partners in supply chain, where the lack of knowledge sharing is one of the major challenges.

Table 1. The Construct of External Push

\begin{tabular}{|c|c|}
\hline Variables & Brief Explanation \\
\hline $\begin{array}{l}\text { Competitive } \\
\text { Pressure/Comp } \\
\text { etition }\end{array}$ & $\begin{array}{l}\text { Small businesses' knowledge sharing } \\
\text { initiatives could be pushed by tough } \\
\text { competition in the market place. }\end{array}$ \\
\hline New Markets & $\begin{array}{l}\text { Small businesses' knowledge sharing } \\
\text { initiatives could be pushed by new market } \\
\text { (i.e. in other cities and countries). }\end{array}$ \\
\hline $\begin{array}{l}\text { Customer } \\
\text { Expectation and } \\
\text { Demand }\end{array}$ & $\begin{array}{l}\text { Small businesses' knowledge sharing } \\
\text { initiatives could be pushed by customers' } \\
\text { increasing demand for value-for-money } \\
\text { products and services. }\end{array}$ \\
\hline s & $\begin{array}{l}\text { Small businesses' knowledge sharing } \\
\text { initiatives could be pushed by the need for } \\
\text { sharing knowledge with their supply chain } \\
\text { partners. }\end{array}$ \\
\hline & $\begin{array}{l}\text { Small businesses' knowledge sharing } \\
\text { initiatives could be pushed by increased } \\
\text { popularity of knowledge management in } \\
\text { the industry. }\end{array}$ \\
\hline $\begin{array}{l}\text { Influence from } \\
\text { External } \\
\text { Consultants }\end{array}$ & $\begin{array}{l}\text { Small businesses' knowledge sharing } \\
\text { initiatives could be pushed by } \\
\text { recommendation from external consultants. }\end{array}$ \\
\hline $\begin{array}{l}\text { Opportunities } \\
\text { Arising from } \\
\text { Technology } \\
\text { Development }\end{array}$ & $\begin{array}{l}\text { Small businesses' knowledge sharing } \\
\text { initiatives could be pushed by opportunities } \\
\text { arising from technology development. }\end{array}$ \\
\hline $\begin{array}{l}\text { Regulations and } \\
\text { Policies }\end{array}$ & $\begin{array}{l}\text { Small businesses' knowledge sharing } \\
\text { initiatives could be pushed by relevant } \\
\text { regulations and policies. }\end{array}$ \\
\hline \multicolumn{2}{|c|}{$\begin{array}{l}\text { One important motivation for adopting an } \\
\text { innovation is to gain social status, i.e. following the } \\
\text { fashion/trend }{ }^{36} \text {. Since knowledge management is one of } \\
\text { the significant buzzwords in the late } 90 \text { 's and the new } \\
\text { millennium, small businesses may follow the trend and } \\
\text { fashion to embark. Small businesses could also adopt } \\
\text { knowledge management as a result of the inspiration } \\
\text { from the outside knowledge management researchers } \\
\text { and consultants. Such opinion is in line with Rogers's } \\
\text { view }{ }^{36} \text { that agents' promotion effort is an important } \\
\text { determinant of innovation adoption. As the resource }\end{array}$} \\
\hline
\end{tabular}


scarcity is one of the major factors that hinder the adoption of knowledge management, small businesses may be sensitive to external supports including technology and government policies in their decision in making their knowledge management strategy.

Variables of the Internal Pull are identified and explained in Table 2.

Table 2. The Construct of Internal Pull

\begin{tabular}{|l|l|}
\hline Variables & Brief Explanation \\
\hline Business & $\begin{array}{l}\text { Small businesses' knowledge sharing } \\
\text { initiatives could be pulled by the need for } \\
\text { business succession. }\end{array}$ \\
\hline $\begin{array}{l}\text { Business } \\
\text { Growth }\end{array}$ & $\begin{array}{l}\text { Small businesses' knowledge sharing } \\
\text { initiatives could be pulled by the need for } \\
\text { expanding their business domestically or/and } \\
\text { internationally. }\end{array}$ \\
\hline $\begin{array}{l}\text { Business } \\
\text { Impresses }\end{array}$ & $\begin{array}{l}\text { Small businesses' knowledge sharing } \\
\text { initiatives could be pulled by the need for } \\
\text { business process improvement. }\end{array}$ \\
\hline $\begin{array}{l}\text { The Need for } \\
\text { Problem } \\
\text { Solving }\end{array}$ & $\begin{array}{l}\text { Small businesses' knowledge sharing } \\
\text { initiatives could be pulled by the need for } \\
\text { solutions of problems. }\end{array}$ \\
\hline $\begin{array}{l}\text { The Need for } \\
\text { Better } \\
\text { Knowledge } \\
\text { Management }\end{array}$ & $\begin{array}{l}\text { Small businesses' knowledge sharing } \\
\text { initiatives could be pulled by the need for } \\
\text { better managing their knowledge. }\end{array}$ \\
\hline $\begin{array}{l}\text { New } \\
\text { Opportunities } \\
\text { Identification }\end{array}$ & $\begin{array}{l}\text { Small businesses' knowledge sharing } \\
\text { activities could be pulled by the need for } \\
\text { identifying and exploring new business } \\
\text { opportunities. }\end{array}$ \\
\hline $\begin{array}{l}\text { People's } \\
\text { Initiatives }\end{array}$ & $\begin{array}{l}\text { Small businesses' knowledge sharing } \\
\text { initiatives could be pulled by people’s } \\
\text { initiatives for better managing knowledge. }\end{array}$ \\
\hline $\begin{array}{l}\text { Strategic } \\
\text { Alliance }\end{array}$ & $\begin{array}{l}\text { Small businesses' knowledge sharing } \\
\text { initiatives could be pulled by the need for } \\
\text { establishing strategic alliance. }\end{array}$ \\
\hline
\end{tabular}

The succession and growth of small businesses depends on how well they manage the knowledge of their staff ${ }^{44}$. Rogers ${ }^{36}$ suggested that organisational problems may create perceived needs of an innovation, which has a direct relationship with business process improvement $^{34}$. Expanding business, identifying and exploring new business opportunities ${ }^{66}$ and dealing with business succession issues ${ }^{67,68,69}$ could also trigger businesses' initiatives in better sharing knowledge. Because of the characteristic of cross functionality of staff, it is essential for small businesses to share experience and skills among the staff, especially transferring them from senior to junior staff. Small businesses also have a need for knowledge from outside and exchange knowledge with other organisations of strategic alliance ${ }^{13}$.

Variables of the Behavioural Attitude are identified and explained in Table 3.

Resource scarcity prevents small businesses from having a comprehensive knowledge management system. Knowledge must be leveraged so that business goals can be achieved in an effective and efficient manner $^{62}$. Knowledge management strategy should inherit the ad hoc fashion. A suitable handling of knowledge is a particularly important factor as to whether a business survives or otherwise ${ }^{13}$.

There is a positive relationship between knowledge management practice and innovation ${ }^{13}$. Rogers ${ }^{36}$ described five attributes of innovation, which are perceived as influencing factors for adoption of the innovation. In this paper, these attributes are used as evaluation factors for the benefits and suitability for achieving business goals. Small businesses may determine the knowledge sharing strategy based on the measurement.

Table 3. The Construct of Behavioural Attitude

\begin{tabular}{|l|l|}
\hline Variables & Brief Explanation \\
\hline Relative & $\begin{array}{l}\text { A systematic and holistic approach of } \\
\text { knowledge sharing is better than other } \\
\text { approaches (i.e. using IT only or managing } \\
\text { people only approaches) }\end{array}$ \\
\hline Compatibility & $\begin{array}{l}\text { Sharing knowledge is consistent with small } \\
\text { businesses' organisational goals and is } \\
\text { compatible with their current practices. }\end{array}$ \\
\hline Complexity & $\begin{array}{l}\text { For small businesses, knowledge sharing in a } \\
\text { holistic and systematic way is not a mission } \\
\text { impossible. }\end{array}$ \\
\hline Trialability & $\begin{array}{l}\text { Knowledge sharing could be easily tested } \\
\text { before a full-scale implementation in small } \\
\text { businesses. }\end{array}$ \\
\hline Observability & $\begin{array}{l}\text { The benefits of knowledge sharing are visible } \\
\text { for small businesses. }\end{array}$ \\
\hline
\end{tabular}

Variables of the Decision-makers' Proficiency are identified and explained in Table 4.

Small businesses adopt informal organisation structure, and decision-making is limited to one person $^{55}$, who is normally the business owner. These owners may not have seen the value of knowledge management ${ }^{50}$, and may not have fully exploited the benefits of knowledge management ${ }^{10}$. Based on an Australian study, Kaye ${ }^{70}$ identified five main problems with small businesses: a lack of vision (thus no strategy) by the owner; business owners' lack of passion in their 
business; lack of plan (leading to low confidence in taking necessary risks); inappropriate management of owners' time; and business owners' unwillingness and failure in investing in knowledge. Rogers ${ }^{36}$, Grover ${ }^{71}$ and Sultan \& Chan $^{72}$ suggested that individual leader's attitude toward change and risk is positively linked to organisational innovativeness.

Table 4. The Construct of Decision-makers' Proficiency

\begin{tabular}{|l|l|}
\hline Variables & Brief Explanation \\
\hline $\begin{array}{l}\text { Decision-maker's } \\
\text { the Imptanding of } \\
\text { and Value of } \\
\text { Knowledge }\end{array}$ & $\begin{array}{l}\text { The decision-maker's understanding of } \\
\text { the importance and value of knowledge } \\
\text { will greatly enhance knowledge sharing } \\
\text { activities in a small businesses. }\end{array}$ \\
\hline $\begin{array}{l}\text { Decision-maker's } \\
\text { Experience of } \\
\text { Knowledge } \\
\text { Sharing }\end{array}$ & $\begin{array}{l}\text { The decision-maker's positive } \\
\text { knowledge sharing experience will } \\
\text { greatly enhance knowledge sharing } \\
\text { activities in a small business. }\end{array}$ \\
\hline $\begin{array}{l}\text { Decision-maker's } \\
\text { Knowledge \& } \\
\text { Skills of Sharing } \\
\text { Knowledge }\end{array}$ & $\begin{array}{l}\text { The decision-maker's knowledge \& } \\
\text { skills of sharing knowledge will greatly } \\
\text { enhance knowledge sharing activities in a } \\
\text { small business. }\end{array}$ \\
\hline $\begin{array}{l}\text { Decision-maker's } \\
\text { Leadership and } \\
\text { Commitment to } \\
\text { Knowledge } \\
\text { Sharing }\end{array}$ & $\begin{array}{l}\text { The decision-maker's leadership and } \\
\text { commitment to knowledge sharing will } \\
\text { greatly enhance knowledge sharing } \\
\text { activities in a small business. }\end{array}$ \\
\hline $\begin{array}{l}\text { Decision-maker's } \\
\text { Initiatives of } \\
\text { Knowledge } \\
\text { Sharing }\end{array}$ & $\begin{array}{l}\text { The decision-maker's initiatives of } \\
\text { knowledge sharing will greatly enhance } \\
\text { knowledge sharing activities in a small } \\
\text { business. }\end{array}$ \\
\hline $\begin{array}{l}\text { Decision-maker's } \\
\text { Innovativeness } \\
\text { (Willingness to } \\
\text { Try New Things) }\end{array}$ & $\begin{array}{l}\text { The decision-maker's willingness to try } \\
\text { new things will greatly enhance } \\
\text { knowledge sharing activities in a small } \\
\text { business. }\end{array}$ \\
\hline $\begin{array}{l}\text { Decision-maker's } \\
\text { Risk Taking } \\
\text { Attitude }\end{array}$ & $\begin{array}{l}\text { The decision-maker's Risk Taking } \\
\text { positive risk-taking attitude toward } \\
\text { sharing knowledge will greatly enhance } \\
\text { knowledge sharing activities in a small } \\
\text { business. }\end{array}$ \\
\hline
\end{tabular}

Variables of the Subject Norms are identified and explained in Table 5.

Knowledge sharing promises to enhance competitive advantage $^{30}$, but at costs. Because of resource scarcity, a small business may not have money on knowledge management initiatives ${ }^{37}$, and therefore cannot gain the competitive advantages, while some others have taken the first-mover advantage. Small businesses have to consider the opportunity cost of not taking initiative in knowledge management. There exists a subjective norm or a perceived social pressure ${ }^{73}$ to share knowledge in the industry. Subject norms describe the social influence that may affect a person's intention to share knowledge. People often take action based on their perceptions of what others think they should do. Knowledge sharing efforts can be influenced by others, such as leaders, peers and respected people.

Table 5. The Construct of Subject Norms

\begin{tabular}{|l|l|}
\hline Variables & Brief Explanation \\
\hline $\begin{array}{l}\text { Peer Business } \\
\text { Pressure }\end{array}$ & $\begin{array}{l}\text { Peer businesses have influences on small } \\
\text { businesses' knowledge sharing activities. }\end{array}$ \\
\hline $\begin{array}{l}\text { Following } \\
\text { Industry } \\
\text { Leaders' Lead }\end{array}$ & $\begin{array}{l}\text { Some small businesses will simply follow } \\
\text { leaders in knowledge sharing activities. }\end{array}$ \\
\hline $\begin{array}{l}\text { Respected } \\
\text { People }\end{array}$ & $\begin{array}{l}\text { Small businesses (especially the decision- } \\
\text { makers of small businesses) may start } \\
\text { sharing knowledge as per the } \\
\text { encouragement from respected people. }\end{array}$ \\
\hline Staff Support & $\begin{array}{l}\text { Small businesses (especially the decision- } \\
\text { makers of small businesses) may start } \\
\text { sharing knowledge as per the } \\
\text { encouragement from company staff. }\end{array}$ \\
\hline
\end{tabular}

Variables of the Intention are identified and explained in Table 6.

Table 6. The Construct of Intention

\begin{tabular}{|l|l|}
\hline Variables & Brief Explanation \\
\hline $\begin{array}{l}\text { Knowledge } \\
\text { Sharing } \\
\text { within the } \\
\text { Business }\end{array}$ & $\begin{array}{l}\text { Small businesses' intention to share } \\
\text { knowledge (especially tacit knowledge) } \\
\text { within business will be critical for the } \\
\text { success and continuity of small businesses. }\end{array}$ \\
\hline $\begin{array}{l}\text { Knowledge } \\
\text { Sharing with } \\
\text { Suppliers and } \\
\text { Business } \\
\text { Partners }\end{array}$ & $\begin{array}{l}\text { Small businesses have the intention to share } \\
\text { knowledge with suppliers and business } \\
\text { partners to improve their supply chains. }\end{array}$ \\
\hline $\begin{array}{l}\text { Knowledge } \\
\text { Sharing with } \\
\text { Customers }\end{array}$ & $\begin{array}{l}\text { Small businesses have the intention to share } \\
\text { knowledge with customers to provide } \\
\text { customers with better products and services. }\end{array}$ \\
\hline $\begin{array}{l}\text { Knowledge } \\
\text { Sharing with } \\
\text { Government } \\
\text { Agencies }\end{array}$ & $\begin{array}{l}\text { Small businesses have the intention to share } \\
\text { knowledge with government agencies to } \\
\text { enhance their reputation, strengthen their } \\
\text { relationship with them, and reduce } \\
\text { unexpected events. }\end{array}$ \\
\hline $\begin{array}{l}\text { Knowledge } \\
\text { Sharing with } \\
\text { Competitors }\end{array}$ & $\begin{array}{l}\text { Small businesses have the intention to share } \\
\text { knowledge with competitors to create a win- } \\
\text { win situation for both sides (co-opetition). }\end{array}$ \\
\hline
\end{tabular}

Different attitudes exist toward knowledge sharing exist. For example, some people are protective and uphold knowledge. Those people possess knowledge and won't share it around since they believe that knowledge is power. Not everyone in organisation is comfortable with the management fads and buzzwords 
like knowledge management. On the other hand there are always people wanting to manage knowledge more efficiently and officially. They are keen to know what is happening and to share knowledge. It is human being's nature to resist knowledge sharing for such fears as job security, loss of power and criticism.

Small businesses value relational capital. They use the relational capital and knowledge stemming from their partnerships and collaborative work to increase performance and competitive advantages ${ }^{44,46}$. Moreover, a small business has to take an initiative in knowledge sharing when the partners adopt a knowledge sharing strategy. Specially, knowledge sharing within a supply chain has become common ${ }^{30}$.

Variables of the Actual Knowledge Sharing are identified and explained in Table 7.

A small business shares knowledge not only within the business but also with other stakeholders or even competitors. In practice, there is an issue of control on knowledge: what knowledge is shared and what tools are used. For example, knowledge shared within businesses is tacit in nature ${ }^{45}$, and tools are often not considered as instruments for sharing this knowledge ${ }^{4,44}$. Tools such as social software or internal networking opportunities are less important within small businesses because of the characteristic of proximity in workplace $^{51}$.

Table 7. The Construct of Actual Knowledge Sharing

\begin{tabular}{|l|l|}
\hline Variables & Brief Explanation \\
\hline $\begin{array}{l}\text { Actual Knowledge } \\
\text { Sharing within the } \\
\text { Business }\end{array}$ & $\begin{array}{l}\text { Small businesses share their knowledge } \\
\text { (especially tacit knowledge) within } \\
\text { their business. }\end{array}$ \\
\hline $\begin{array}{l}\text { Actual Knowledge } \\
\text { Sharing with } \\
\text { Suppliers and } \\
\text { Business Partners }\end{array}$ & $\begin{array}{l}\text { Small businesses share knowledge with } \\
\text { suppliers and business partners. }\end{array}$ \\
\hline $\begin{array}{l}\text { Actual Knowledge } \\
\text { Sharing with } \\
\text { Customers }\end{array}$ & $\begin{array}{l}\text { Small businesses share knowledge with } \\
\text { customers. }\end{array}$ \\
\hline $\begin{array}{l}\text { Actual Knowledge } \\
\text { Sharing with } \\
\text { Government } \\
\text { Agencies }\end{array}$ & $\begin{array}{l}\text { Small businesses share knowledge with } \\
\text { government agencies. }\end{array}$ \\
\hline $\begin{array}{l}\text { Actual Knowledge } \\
\text { Sharing with } \\
\text { Competitors }\end{array}$ & $\begin{array}{l}\text { Small businesses share knowledge with } \\
\text { competitors. }\end{array}$ \\
\hline
\end{tabular}

Variables of the Realised Benefits are identified and explained in Table 8.
Table 8. The Construct of Realised Benefits

\begin{tabular}{|c|c|}
\hline Variables & Brief Explanation \\
\hline $\begin{array}{l}\text { Better/ New } \\
\text { Products and } \\
\text { Services }\end{array}$ & $\begin{array}{l}\text { Knowledge sharing has helped small } \\
\text { businesses create better/new services and } \\
\text { innovation which they cannot do before or } \\
\text { on their own. }\end{array}$ \\
\hline Efficiency & $\begin{array}{l}\text { Knowledge sharing has helped small } \\
\text { businesses enhance the efficiency of their } \\
\text { internal operations (i.e. simplifying } \\
\text { workflows, speeding the projects). }\end{array}$ \\
\hline Effectiveness & $\begin{array}{l}\text { Knowledge sharing has helped small } \\
\text { businesses do the right things, i.e. working } \\
\text { on the right projects, markets, etc. }\end{array}$ \\
\hline $\begin{array}{l}\text { People's } \\
\text { Loyalty }\end{array}$ & $\begin{array}{l}\text { Knowledge sharing has enhanced people's } \\
\text { loyalty to the business. }\end{array}$ \\
\hline $\begin{array}{l}\text { Recruitment } \\
\text { and Retention } \\
\text { Strategies }\end{array}$ & $\begin{array}{l}\text { Knowledge sharing has helped small } \\
\text { businesses more effectively recruit people } \\
\text { with required knowledge and retain talent } \\
\text { (knowledge champions). }\end{array}$ \\
\hline $\begin{array}{l}\text { People's } \\
\text { Knowledge } \\
\text { Building }\end{array}$ & $\begin{array}{l}\text { Knowledge sharing has helped small } \\
\text { businesses build people knowledge base } \\
\text { and increase their knowledge, i.e. learning } \\
\text { from others' experience and knowledge. }\end{array}$ \\
\hline $\begin{array}{l}\text { Time \& Cost } \\
\text { Reduction }\end{array}$ & $\begin{array}{l}\text { Knowledge sharing has helped small } \\
\text { businesses save time and money for } \\
\text { organisations through "avoiding } \\
\text { reinventing the wheel". }\end{array}$ \\
\hline $\begin{array}{l}\text { Avoiding Same } \\
\text { Mistakes }\end{array}$ & $\begin{array}{l}\text { Knowledge sharing has helped small } \\
\text { businesses reduce the chances for mistakes } \\
\text { and mediate the risks. }\end{array}$ \\
\hline $\begin{array}{l}\text { Relationship } \\
\text { with Customers }\end{array}$ & $\begin{array}{l}\text { Knowledge sharing has helped small } \\
\text { businesses enhance their relationship with } \\
\text { customers and provide them with better } \\
\text { products \& services. }\end{array}$ \\
\hline $\begin{array}{l}\text { Relationship } \\
\text { with Suppliers } \\
\text { and Business } \\
\text { Partners }\end{array}$ & $\begin{array}{l}\text { Knowledge sharing has helped small } \\
\text { businesses enhance their relationship with } \\
\text { suppliers and business partners and has } \\
\text { helped improve their supply chains. }\end{array}$ \\
\hline $\begin{array}{l}\text { Relationship } \\
\text { with } \\
\text { Government } \\
\text { Agencies }\end{array}$ & $\begin{array}{l}\text { Knowledge sharing has helped small } \\
\text { businesses enhance their relationship with } \\
\text { government agencies and has helped } \\
\text { maintain/improve their reputation, } \\
\text { strengthen their relationship with them, and } \\
\text { reduce unexpected events. }\end{array}$ \\
\hline $\begin{array}{l}\text { Relationship } \\
\text { with } \\
\text { Competitors }\end{array}$ & $\begin{array}{l}\text { Knowledge sharing has helped small } \\
\text { businesses enhance their relationship with } \\
\text { their competitors and has helped them } \\
\text { achieve a win-win situation (co-opetition } \\
\text { has been made possible). }\end{array}$ \\
\hline
\end{tabular}

The aim of knowledge sharing for an organisation is its economic and competitive value ${ }^{8}$. Realizing benefits of managing knowledge is a critical issue for the success of knowledge management ${ }^{74,75,76}$. On the other hand, humans have innate needs to achieve competence, 
autonomy and satisfying relationships ${ }^{77}$. Small businesses should consider all the characteristics examined in Section 3.1 of this paper in determination of the knowledge sharing strategy to achieve appropriate business and individual goals.

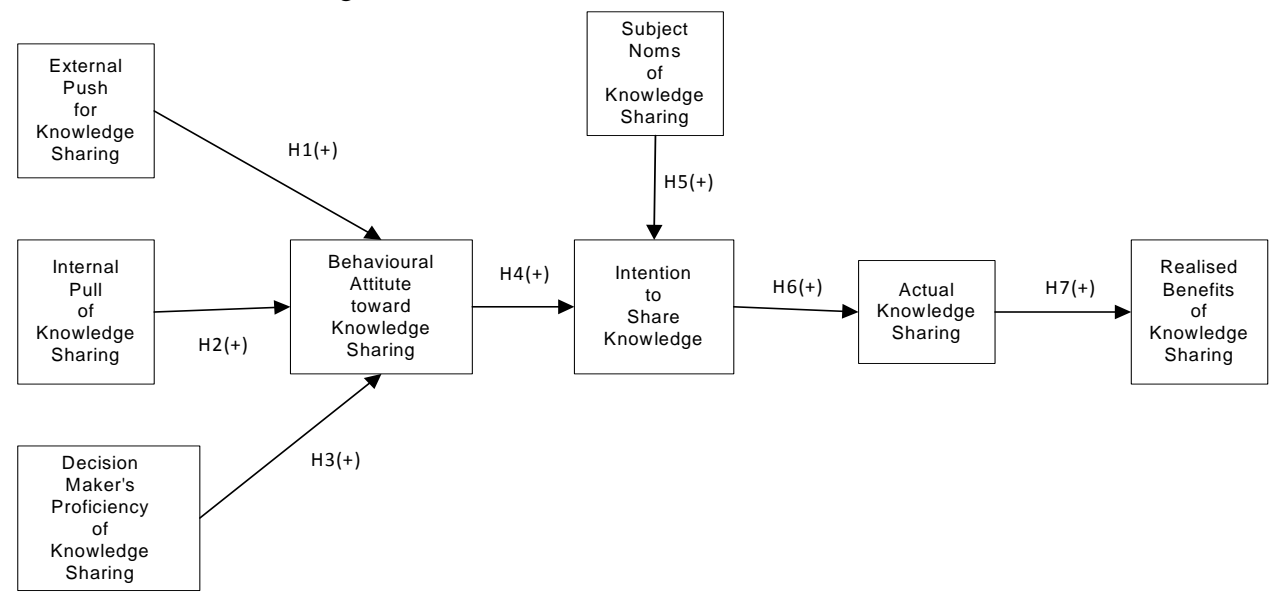

Fig. 2. Proposed Knowledge Sharing Model

The model suggests that:

- the attitude toward knowledge sharing is directly influenced by the external push, internal pull and decision-maker's proficiency;

- the intention to share knowledge is directly affected by the subject norms and the attitude;

- Actual knowledge sharing is determined by the intention; and

- Realised benefits are achieved by actual knowledge sharing.

The hypotheses for the model are presented as follows.

H1: "External push for knowledge sharing" positively influences the "Behavioural attitude toward knowledge sharing".

Ajzen \& Fishbein's TRA ${ }^{38}$ proposes that external push affects the attitudes, which in turn influence the behaviour. Through fostering collaborative practices and knowledge sharing, knowledge management facilitates the learning about the external environment ${ }^{78}$ and the implementation of a successful change management program responding to the external environment ${ }^{65}$. The organisations are implementing knowledge management to learn and respond to their customers better. Through effective knowledge management programs, businesses are also able to provide more enhanced and/or new products and services. Alavi \& Leidner $^{79}$ suggested that customers

\subsection{Knowledge Sharing Model}

Based on the preceding discussion, a research model for knowledge sharing is proposed and shown in Fig. 2. and knowledge about them are most important knowledge domains for small businesses.

H2: "Internal pull of knowledge sharing" positively influences the "Behavioural attitude toward knowledge sharing”.

Ajzen \& Fishbein's TRA ${ }^{38}$ proposed that factors such as organisational needs affect the attitudes, which in turn influence the behaviour. It is widely accepted that by effective management of their knowledge, small businesses could improve their competitiveness and enhance their business performance ${ }^{80,81,82,83,84,85,86,87,88}$. The task of organising and storing existing knowledge is enormous with minimal tangible benefits until the knowledge is reused. Sharing knowledge greatly facilitate the organisation's effort to improve the productivity and maintain the quality, especially when people are dealing with complex projects. Very often when organisations have the growing awareness to manage their knowledge better (i.e. for improving productivity, reducing costs, reaching global markets, etc.) they feel the need for better knowledge sharing to "know what they know" and use that knowledge effectively to avoid reinventing the wheel, and to take better control of their knowledge assets.

H3: "Decision maker's proficiency of knowledge sharing" positively influences the "Behavioural attitude toward knowledge sharing”. 
Ajzen \& Fishbein's TRA ${ }^{38}$ proposed that factors such as decision makers' proficiency of knowledge sharing affect the attitudes, which in turn influence the behaviour. Management and leadership play critical roles in knowledge management ${ }^{89}$. Management provides vision and energy to stimulate and sustain effective knowledge management practices and systems. Leaders have direct impact on the organisation's culture and knowledge management approaches. Without management's commitment and emphasis on knowledge management, people are not likely to take it seriously ${ }^{90}$. Leaders have to take into account issues such as culture, structure, process, training and development. More attention should be given to people since businesses make profits through selling and effectively using their (tacit) knowledge ${ }^{91,92}$. One important challenge for leaders is how they can embed knowledge into day-to-day work to help them do their jobs more effectively and efficiently ${ }^{93}$.

H4: "Behavioural attitude toward knowledge sharing" positively influences the "Intention to share knowledge".

Ajzen \& Fishbein's TRA ${ }^{38}$ proposed that intention is directly influenced by attitude toward knowledge sharing. Based on their study of knowledge sharing practices among members of a virtual professional community in Taiwan, Kuo \& Young ${ }^{94}$ suggested that an individual's attitude has positive influence on his/her intention to share what he/she knows. In addition, past studies, such as Moore ${ }^{95}$, Karahanna et al. ${ }^{96}$, Liker \& Sindi $^{97}$ and Agarwal \& Prasad $^{98}$, pointed out that attitude is positively associated with intention.

H5: "Subject norms" positively influences the "Intention to share knowledge".

Ajzen \& Fishbein's TRA ${ }^{38}$ proposed that intention is directly influenced by subject norms. Hartwick \& Barki $^{99}$ and Taylor \& Todd $^{100}$ indicated that subordinates and superiors are important referent groups for people's decision to adopt an innovation in an organisational environment. Huber ${ }^{101}$ suggested that there is considerable ignorance in the literature on the impacts of the social-psychological forces such as the need to adhere to social norms, the need to comply with organisational norms (the right thing to do) and the need for recognition, on knowledge sharing and participation in the knowledge management systems. In addition, literature, such as Thompson et al. ${ }^{102}$, Liker \& Sindi ${ }^{97}$ and Lucas \& Spitler ${ }^{103}$, had found that subject norms are positively associated with individual's acceptance of new technology.

H6: "Intention to share knowledge" is positively associated with "Knowledge sharing activities".

According to the TRA ${ }^{38}$, people's intention to share (or not to share) knowledge is the immediate determinant of the action of knowledge sharing. Activities related to knowledge sharing are timeconsuming and require a certain level of trust ${ }^{4}$. It is necessary to create a climate of trust where people can share knowledge with confidence ${ }^{89}$. The support from top management, i.e. understanding the importance of knowledge management, commitment, and leadership, is crucial for the success of knowledge management in organisations.

H7: "Knowledge sharing activities" is positively associated with "Realised benefits of knowledge sharing”.

Knowledge sharing will benefit the sharers' organisation and sharers themselves ${ }^{77}$. Potential benefits are a determinant for knowledge sharing. However benefits have not been generally exploited by small businesses ${ }^{10}$. Business owners may not intend to invest in knowledge $^{70}$, and individual knowledge may be regarded as personal assets that will assist an employee in maintaining employment ${ }^{104}$. Management provides vision and energy to stimulate and sustain effective knowledge management practices. Pan \& Scarbrough ${ }^{89}$ suggested that management play critical roles in coordinating various activities of knowledge management, and create knowledge management strategy, technology, structure, knowledge sharing culture and knowledge-focused reward system.

\section{Conclusion and Future Direction}

Small businesses play a dominant role in economy. Given the high failure rate of small businesses, it is hoped that better knowledge sharing activities will contribute in enhancing their performance and sustainability. However, knowledge sharing in small businesses is a topic that has not been well studied in the past but represents a primary concern of knowledge management. This research examines the characteristics of small businesses in terms of knowledge sharing; identifies determinants for knowledge sharing in small businesses, and proposes a research model based on Ajzen \& Fishbein's TRA ${ }^{38}$, Rogers' diffusion of innovation theory ${ }^{36}$ and Lipshitz et al.'s NDM $^{105}$ 
approach. The proposed model will provide small businesses with guidance for knowledge sharing initiatives. Based on the construct and variables of the model, government agencies, policy makers, and other stakeholders can gain enhanced understanding of knowledge sharing in small businesses, and leverage small businesses by appropriate policies to push their knowledge sharing.

Future research will empirically test the proposed research model. Variables in Table 1 through to Table 8 will be defined so that they can be measured. Some other interesting research areas include comparison studies of knowledge sharing in small businesses across different industries in Australia, across countries or cultures, and exploration of other factors influencing knowledge sharing in small businesses.

\section{References}

1. D. Forsaith, D. Fuller, W. Pattinson, P. Sutcliffe \& J. Callachor, Australian Evidence on the Interchangeability of Definitions of a Small Enterprise, Australian Bulletin of Labour, 21(2) (1994) 109-118.

2. ABS (Australian Bureau of Statistics), Small Business in Australia 2001, Australian Bureau of Statistics, Cat. No.1321.0, (2001).

3. ABS (Australian Bureau of Statistics), Counts of Australian Businesses (Including Entries and Exits), Australian Bureau of Statistics, Cat. No.8165.0, (2010)

4. S. Durst \& S. Wilhelm, Knowledge management and succession planning in SMEs, Journal of Knowledge Management, 16(4) (2012) 637-649.

5. R. Coyte, F. Ricceri \& J. Guthrie, The management of knowledge resources in SMEs: an Australian case study, Journal of Knowledge Management, 16(5) (2012) 789807.

6. A. Jashapara, Knowledge Management: An Integrated Approach 2nd edi, Prentice Hall (Essex, England, 2011).

7. K. Dalkir, Knowledge Management in Theory and Practice 2nd edi, The MIT Press (Cambridge, Massachusetts, 2011).

8. P. Hendricks, Why Share Knowledge? The Influence of ICT on the Motivation for Knowledge Sharing, Knowledge and Process Management, 6(2) (1999) 911000.

9. L.Z. Cantu, J.R. Criado \& A.R. Criado, Generation and transfer of knowledge in IT-related SMEs, Journal of Knowledge Management, 13(5) (2009) 243-256.

10. P. Evangelista, E. Esposito, V. Lauro \& M. Raffa, The Adoption of Knowledge Management Systems in Small Firms, Electronic Journal of Knowledge Management, 8(1) (2010) 33-42.
11. N. Steenkamp \& V. Kashyap, Importance and contribution of intangible assets: SME managers' perceptions, Journal of Intellectual Capital, 11(3) (2010) 368-390.

12. C.W. Hofer \& R. Charan, The transition to professional management: mission impossible?, American Journal of Small Business, 9(1) (1984) 1-11.

13. S. Durst \& I.R. Edvardsson, Knowledge management in SMEs: a literature review, Journal of Knowledge Management, 16(6) (2012) 879-903.

14. J. Curran \& R.A. Blackburn, Researching the Small Enterprise, Sage (London, 2001).

15. V. Hutchison \& P. Quintas, Do SMEs do knowledge management? Or simply manage what they know?, International Small Business Journal, 26 (2008) 131-51.

16. R. Ruggles, The state of the notion: knowledge management in practice, California Management Review, 40(3) (1998) 80-89.

17. M. Polanyi, Personal Knowledge: Toward a Post-Critical Philosophy, Routledge and Kegan Paul (London, UK, 1962).

18. D. Bonner, Leading Knowledge Management and Learning, American Society of Training \& Development (Virginia, 2000).

19. I. Nonaka \& H. Takeuchi, The Knowledge-Creating Company-How Japanese Companies Create the Dynamic of Innovation, Oxford University Press, (New York, 1995).

20. I. Nonaka, R. Toyama \& N. Konno, SECI, Ba and Leadership: a Unified Model of Dynamic Knowledge Creation, Long Range Planning, 33 (2000) 5-34.

21. A. Bennet \& D. Bennet, The partnership between organizational learning and knowledge management in C.W. Hosapple (Ed.), Handbook on Knowledge Management, Springer, New York (NY, 2003) 439-55.

22. R. McDermott, Why information technology inspired but cannot deliver knowledge management, California Management Review, 4(4) (1999) 103-17.

23. R.L. Chase, The knowledge-based organization: an international survey, The Journal of Knowledge Management, 1(1) (1997) 38-49.

24. The Conference Board, Beyond Knowledge Management: New Ways to Work and Learn, The Conference Board Inc (New York, USA, 1999).

25. The Delphi Group, Delphi Research Identifies Culture as Key Hurdle to Knowledge Management, (1997).

26. S. Zyngier, Knowledge management obstacles in Australia, Proceedings of The Xth European Conference on Information Systems, Gdansk, Poland, June 2002.

27. H.C. Chang, M.T. Tsai \& C.L. Tsai, Complex organizational knowledge structures for new product 
development teams, Journal of Knowledge-based Systems, 24 (2011) 652-661.

28. R. Vandaie, The role of knowledge management in successful ERP implementation projects, Journal of Knowledge-based Systems, 21 (2008) 920-926.

29. M. Mazzie, Key challenges facing the evolution of knowledge management in T.K. Srikantaiah \& M.E.D. Koenig (eds), Knowledge Management for the Information Professional, Information Today, Inc. (Medford, New Jersey, USA, 2000) 99-114.

30. D.G. Bell, R. Giordano \& P. Putz, Inter-firm Sharing of Process Knowledge: Exploring Knowledge Markets, Knowledge and Process Management, 9(1) (2002) 12-22.

31. J.A. Cannon-Bowers \& E. Salas (Eds.), Decision Making Under Stress: Implications for Training and Simulation, American Psychological Association (New York, 1998).

32. B. Crandall \& K. Getchell-Reiter, Critical Decision Method: A Technique for Eliciting Concrete Assessment Indicators from Intuition of NICU Nurses, Advances in Nursing Science, 16(1) (1993) 42-51.

33. J. Shanteau, Competence in Experts: The Role of Task Characteristics, Organizational Behaviour and Human Decision Processes, 53 (1992) 252-266.

34. W.Y. Wang \& C. Chang, Intellectual capital and performance in causal models: evidence from the information technology industry in Taiwan, Journal of Intellectual Capital, 6(2) (2005) 222-36.

35. H. Santos-Rodrigues, Intellectual Capital and Innovation: A Case Study of a Public Healthcare organisation in Europe, The Electronic Journal of Knowledge Management, 11(4) (2013) 361-372.

36. E.M. Rogers, Diffusion of Innovations, 4th ed, The Free Press (New York, USA, 1995).

37. K. Fink \& C. Ploder, Knowledge Management toolkit for SMEs, International Journal of Knowledge Management, 5(1) (2009) 6-60.

38. I. Ajzen \& M. Fishbein, Understanding Attitudes and Predicting Social Behavior, Prentice-Hall (Englewood Cliffs, NJ, 1980).

39. B.H. Sheppard, J. Hartwick \& P.R. Warshaw, The Theory of Reasoned Action: A Meta-Analysis of Past Research with Recommendations for Modifications and Future Research, Journal of Consumer Research, 15 (December 1988) 325-343.

40. F.D. Davis, P.B. Bagozzi \& P.R. Warshaw, User Acceptance of Computer Technology: A Comparison of Two Models, Management Science, 35(8) (1989) 9821003.

41. R.P.Bagozzi, H. Baumgartner \& Y. Youjae, State Verus Action Orientation and the Theory of Reasoned Action: An Application to Coupon Usage, Journal of Consumer Research, 18(4) (1992) 505-518.
42. R. Agarwal \& J. Prasad, The Role of Innovation Characteristics and Perceived Voluntariness in the Acceptance of Information Technologies, Decision Sciences, 28(3) (1997) 557-582.

43. J. Wee \& A. Chua, The peculiarities of knowledge management processes in SMEs: the case of Singapore, Journal of Knowledge Management, 17(6) (2013) 958972.

44. K.C. Desouza \& Y. Awazu, Knowledge Management at SMEs: Five Peculiarities, Journal of Knowledge Management, 10(1) (2006) 32-43.

45. C.O. Egbu, S. Hari \& S.H. Renukappa, Knowledge Management for Sustainable Competitiveness in Small and Medium Surveying Practices, Structural Survey, 23(1) (2005) pp 7-21.

46. K.Y. Wong \& E.M. Aspinwall, Characterizing knowledge management in the small business environment, Journal of Knowledge Management, 8(3) (2004) 44-61.

47. J.C. Jarillo, Entrepreneurship and growth: the strategic use of external resources, Journal of Business Venturing, 4(2) (1989) 133-47.

48. M. Hudson, A. Smart \& M. Bourne, Theory and practice in SME performance measurement systems, International Journal of Operations \& Production Management, 21(8) (2001) 1096-115.

49. M. Carney, Corporate Governance Competitive Advantage in Family-Controlled Firms. Entrepreneurship Theory \& Practice, 29 (2005) 249-265.

50. M.B. Nunes, F. Annansingh, B. Eaglestone \& R. Wakefield, Knowledge management issues in knowledgeintensive SMEs, Journal of Documentation, 62(1) (2006) 101-19.

51. G. Neumann \& E. Tomé, The Changing Role of Knowledge in Companies: How to Improve Business Performance Through Knowledge, Electronic Journal of Knowledge Management, 9(1) (2011) 57-72.

52. D. Hislop, Knowledge Management in Organizations: A Critical Introduction, Oxford University Press (Oxford, 2005).

53. S. Cohen \& N. Kaimenakis, Intellectual capital and corporate performance in knowledge intensive SMEs, The Learning Organization, 14(3) (2007) 241-62.

54. S. Bridge, K. O’Neill \& S. Cromi, Understanding Enterprise, Entrepreneurship and Small Business, 2nd ed., Palgrave Macmillan (Basingstoke and New York, NY, 2003).

55. N. Culkin \& D. Smith, An emotional business: a guide to understanding the motivations of small business decision takers, Qualitative Market Research: An International Journal, 3(3) (2000) 145-57. 
56. R.F. Daft, Understanding the Theory and Design of Organizations, Thomson South-Western (Mason, OH, 2007).

57. B. Dunn, Family Enterprises In The Uk: A Special Sector?, Family Business Review, 2 (1996) 221-235.

58. J. St-Pierre \& J. St-Pierre, Intangible assets and performance analysis on manufacturing SMEs, Journal of Intellectual Capital, 12 (2011) 202-223.

59. T.W.Y. Man, T. Lau \& K.F. Chan, The competitiveness of small and medium enterprises: a conceptualization with focus on entrepreneurial competencies, Journal of Business Venturing, 17(2) (2002) 123-142.

60. C.D. Ittner, Does measuring intangibles for management purposes improve performance? A review of the evidence, Accounting and Business Research, 38(3) (2008) 261-72.

61. T. Cater \& B. Cater, (In)tangible resources as antecedents of a company's competitive advantage and performance, Journal for East European Management Studies, 14(2) (2009) 186-209.

62. K. Fink \& C. Ploder, Knowledge process moeling in SME and cost-efficient software support: Theoretical framework and empirical studies. In: M. Khosrow-Pour (Ed.), Managing worldwide operations and communications with information technology, 479-484, IGI Publishing (Hershey, PA, 2007).

63. K.Y. Wong, \& E. Aspinwall, An empirical study of the important factors for knowledge-management adoption in the SME sector, Journal of Knowledge Management, 9(3) (2005) 64-82.

64. M. Ward, Why your corporate culture isn't working and what to do about it, Part 1, Organizational Culture and Change, Gower (London, 1994).

65. S. Moffet, R. McAdam \& S. Parkinson, An empirical analysis of knowledge management applications, Journal of Knowledge Management, 7(3) (2003) 6-26.

66. B.R. Smith, C.H. Matthews \& M.T. Schenkel, Differences in entrepreneurial opportunities: The role of tacitness and codification in opportunity identification, Journal of Small Business Management, 47(1) (2009) 3857.

67. F. Chirico \& W. Laurier, The creation, sharing and transfer of knowledge in family business, Journal of Small Business and Entrepreneurship, 21(4) (2008) 413434.

68. R.N. Trevinyo-Rodriguez \& N. Bontis, Family ties and emotions: a missing piece in the knowledge transfer puzzle, Journal of Small Business and Enterprise Development, 17(3) (2010) 418-436.

69. E. Bracci \& E. Vagnoni, Understanding small family business succession in a knowledge management perspective, The IUP Journal of Knowledge Management, 9(1) (2011) 1-36.

70. T. Kaye, Small is not so Beautiful, The Australian, Nov 30, 2007, available at:

http://www.theaustralian.news.com.au/story/0,25197,228 11120-5010941,00.html (accessed on Feb 20, 2008).

71. V. Grover, An empirically derived model for the adoption of customer-based interorganizational systems, Decision Sciences, 24(3) (1993) 603-640.

72. F. Sultan \& L. Chan, The adoption of new technology: the case of object-oriented computing in software companies, IEEE Transactions on Engineering Management, 47(1) (2000) 106-125.

73. I. Ajzen, The theory of planned behavior, Organizational Behavior and Human Decision Processes, 50(2) (1991) 179-211.

74. Y.F. Wen, An effective measurement model for knowledge management, Journal of Knowledge-based Systems, 22 (2009) 363-367.

75. W.W. Wu, Y.T. Lee, M.L. Tseng \& Y.H. Chang, Data Mining for exploring hidden patterns between KM and its performance, Journal of Knowledge-based Systems, 23 (2010) 397-401.

76. Y. Xu \& A. Bernard, Quantifying the value of knowledge within the context of product development, Journal of Knowledge-based Systems, 24 (2011) 166-175.

77. C.L. Witherspoon, J. Bergner, C. Cockrell \& D.N. Stone, Antecedents of organizational knowledge sharing: a meta-analysis and critique, Journal of Knowledge Management, 17(2) (2013) 250-277.

78. M. Lemon \& P.S. Sahota, Organizational Culture as a Knowledge Repository for Increased Innovative Capacity, Technovation, 24 (2004) 483-498.

79. M. Alavi \& D.E. Leidner, Knowledge management and knowledge management systems: conceptual foundations and research issues, MIS Quarterly, 25(1) (2001) 107146.

80. R.S. Frey, Small business knowledge management success story-This stuff really works!, Knowledge and Processes Management, 9(3) (2002) 172-177.

81. J. Clarke \& P. Turner, Global Competition and the Australian Biotechnology Industry: Developing a Model of SMEs Knowledge Management Strategies, Knowledge and Process Management, 11(1) (2004) 38-64.

82. P.L. Liu, W.C. Chen \& C.H. Tsai, An empirical study on the correlation between knowledge management capability and competitiveness in Taiwan's industries, Technovation, 24 (2004) 971-999.

83. S. Salojarvi, P. Furu \& K.K. Sveiby, Knowledge management and growth in Finnish SMEs, Journal of Knowledge Management, 9(2) (2005) 103-122. 
84. F. Abeson \& M.A. Taku, Knowledge source and small business competitiveness, Competition Forum, 4(2) (2006) 464-469.

85. S. Thornhill, Knowledge, innovation and firm performance in high- and low-technology regimes, Journal of Business Venturing, 21 (2006) 687-703.

86. F. Abeson \& M.A. Taku, Knowledge source and small business competitiveness, Competitiveness Review: An International Business Journal, 19(2) (2009) 88-95.

87. T.S. Kiessling, R.G. Richey, J. Meng \& M. Dabic, Exploring knowledge management to organizational performance outcomes in a transitional economy, Journal of World Business, 44 M. (2009) 421-433.

88. G.P. West \& T.W. Noel, The impact of knowledge resources on new venture performance, Journal of Small Business Management, 47(1) (2009) 1-22.

89. S.L. Pan \& H. Scarbrough, Knowledge Management in Practice: An Exploratory Case Study, Technology Analysis \& Strategic Management, 11(3) (1999) 359-374.

90. K.B. De Tienne, G. Dyer, C. Hoopes \& S. Harris, Toward a Model of Effective Knowledge Management and Directions for Future Research: Culture, Leadership, and CKOs, Journal of Leadership and Organizational Studies, 10(4) (2004) 26-43.

91. K. Sveiby, Small Knowledge Companies-Wave of the Future (1995), available at : http://www.sveiby.com.au/KnowledgeOrganizationsAust. html (accessed on 16 Sept, 1999).

92. B. Lioyd \& T.A. Stewart, Leadership and Knowledge Management, Leadership \& Organization Development Journal, 23(5/6) (2002) 288-292.

93. M.D. Lytras, A interview with Tom Davenport, AIS SIGSEMIS Bulletin, 2(2) (2005).

94. F.Y. Kuo \& M.L. Young, Predicting knowledge sharing practices through intention: A test of competing models, Computers in Human Behavior, 24 (2008) 2697-2722.

95. G.C. Moore, End-user computing and office automation: a diffusion of innovation perspectives, INFOR, 25(3) (1987) 214-235.

96. E. Karahanna, D.W.Straub \& N.L. Chervany, Information Technology adoption across time: a cross-sectional comparison of pre-adoption and post-adoption beliefs, MIS Quarterly, 23(2) (1999) 183-213.

97. J.K. Liker \& A.A. Sindi, User acceptance of expert systems: A test of the theory of reasoned action, Journal of Engineering and Technology Management, 14(2) (1997) 147-173.

98. R. Agarwal \& J. Prased, Are Individual Differences Germane to The Acceptance of New Information Technologies, Decision Sciences, 30(2) (1999) 361-391.
99. J. Hartwick \& Barki, Explaining the role of user participation in information system use, Management Science, 40(4) (1994) 440-465.

100.S. Taylor \& P.A. Todd, Understanding information technology usage: a test of competing models, Information Systems Research, 6(2) (1995) 145-177.

101.G.P. Huber, Transfer of knowledge in knowledge management systems: unexplored issues and suggested studies, European Journal of Information Systems, 10(2) (2001) 72-79.

102. R.L. Thompson, C.A. Higgins \& J.M. Howell, Personal computing: toward a conceptual model of utilization, MIS Quarterly, 15(1) (1991) 125-143.

103.H.C. Lucas \& V.K. Spitler, Technology use and performance: a field study of broker workstations, Decision Sciences, 30(2) (1999) 291-311.

104. L. Henry, Intellectual capital in a recession: evidence from UK SMEs, Journal of Intellectual Capital, 14(1) (2013) 84-101.

105. R. Lipshitz, G. Klein, J. Orasanu \& E. Salas, Taking Stock of Naturalistic Decision Making, Journal of Behavioural Decision Making, 14 (2001) 331-352. 